\title{
Effect of legume-based cropping systems on nitrogen mineralization potential of Vertisol*
}

\author{
S.P. Wani, T.J. Rego, S. Rajeswari and K.K. Lee \\ Soils and Agroclimatology Division (SACD), International Crops Research Institute for the Semi-Arid tropics \\ (ICRISAT), PAtancheru P.O. Andhra Pradesh 502 324, India**
}

Received 20 September 1994. Accepted in revised form 23 March 1995

Key words: cropping system, legumes, $\mathrm{N}$ mineralization, $\mathrm{N}$ potential, rotation effects

\begin{abstract}
The quantity and patterns of net mineralization of soil nitrogen $(\mathrm{N})$ were studied in Vertisols under different cropping systems in the semi-arid tropical areas. Eight cropping systems were selected; three contained pigeonpea (PP), one contained PP and cowpea (COP), and two contained chickpea (CP) as legume component crops, one included sequence cropping with nonlegumes during the rainy and postrainy seasons, and one system was kept fallow (F) during the rainy season and sown to sorghum (S) during the postrainy season. Cropping systems with PP as a component crop increased mineralizable $\mathbf{N}\left(\mathrm{N}_{o}\right)$ content two-fold in the soil compared with fallow + sorghum $(\mathrm{F}+\mathrm{S})-\mathrm{F}+\mathrm{S}$ system. The $\mathrm{N}$ mineralization rate constant $(\mathrm{k})$ was not significantly affected by previous cropping history of the soil; however, a numerically higher rate constant was observed in the COP/PP intercrop, followed by sequential $\mathrm{S}+$ safflower (SF) system as compared to the other soils. Mineral $\mathrm{N}$ accumulation curves for six soils were more accurately described by the exponential model than the linear model. The active $\mathrm{N}$ fraction $\left(\mathrm{N}_{o} / \mathrm{N}_{\mathrm{tor}} \%\right)$ varied between 8 and $16 \%$ for different systems and a direct relationship was observed between $N_{o} / N_{\text {tot }}$ and total $\mathrm{N}$ for the soils under diverse cropping systems.
\end{abstract}

\section{Introduction}

Legumes are grown as intercrops or in rotation with cereals in the semi-arid tropics (SAT) and are important components of sustainable farming systems (Willey et al., 1989). Legumes often increase the yield of a subsequent cereal crop grown on the same soil as compared to the yield of a cereal grown after a nonlegume crop (Kumar Rao et al., 1983; Wani et al., 1991). Although cereal crops benefit from biological $\mathrm{N}$ fixation (BNF) and the soil N-conserving effect of the preceding legume-Rhizobium symbiosis, several reports suggest non- $N$ "rotational effects" on soil properties and successive crops (Cook, 1988; Fyson and Oaks, 1990; Wani et al., 1991). The relation between cropping systems and the quantity and quality of soil organic matter has been inferred from studies of chemical and biological soil parameters (Birch and

\footnotetext{
* ICRISAT JA (1638)

** FAX no corresponding author: +9140 241239
}

Dougall, 1967; Campbell et al., 1991; Wani et al., 1994a). Recently, measurements of microbial biomass (McGill et al., 1986; Wani et al., 1994b), potentially mineralizable $\mathrm{N}\left(\mathrm{N}_{0}\right)$ and mineralizable $\mathrm{C}$ (Stanford and Smith, 1972; Wani et al., 1994a) have been used to monitor biologically meaningful changes in the quantity and quality of soil organic matter. Some increases in soil organic matter content and $\mathrm{N}$ mineralization potential of Gray Luvisols have been attributed to perennial forages and legumes grown in rotations with cereals (Campbell et al., 1991; Poyser et al., 1957; Wani et al., 1994a). Similarly, some increase in total $\mathrm{N}$ content of Vertisol cropped with pigeonpea (PP) or cowpea (COP) in rotation with nonlegumes for 8 years were observed in India. No such increase in total nitrogen content of the soil was observed for chickpea (CP) (Rego and Burford, 1992). However, Janzen (1987) observed no difference in organic matter content and $\mathrm{N}$ mineralization potential of a Dark Brown Chernozemic soil following either alfalfa and 
crested wheat grass in rotation with wheat or continuous wheat cropping when neither system was fertilized. In contrast, potentially mineralizable $\mathrm{N}$ and total soil $\mathrm{N}$ were significantly lower in rotations containing a fallow period. The total quantity of organic matter changes more slowly than do the most active components. Potentially mineralizable $\mathrm{N}$, i.e. the initial pool of mineralizable $\mathrm{N}$ at time zero $\left(\mathrm{N}_{o}\right)$ may represent a part of the "active fraction". McGill (1983) hypothesized that until the active fraction reached a steady state, a direct relationship would exist between total soil organic $\mathrm{N}$ and $\mathrm{N}_{o} / \mathrm{N}_{\text {tot }}$; thereafter the trend would reverse. McGill et al. (1988) showed an inverse relation between $\mathrm{N}_{o} / \mathrm{N}_{\text {tot }}$ using the published data of Campbell and Souster (1982) for virgin prairie soils. There remains a need to determine the changes in $\mathrm{N}$ supplying capacity and total soil $\mathrm{N}$ among cropping systems in the SAT as a prelude to determining the influence of legume-based cropping systems on the growth of successive crops in rotation. Long-term crop rotations at the International Crops Research Institute for the Semi-Arid Tropics (ICRISAT) at Patancheru, India provide a suitable site to examine this issue, that mineralizable $\mathrm{N}$ provides an index of potential $\mathrm{N}$ supply for crop growth and also an estimate of the "active $N$ " fraction. The objectives of this study were: i) to test the hypothesis that the quantity of active soil $\mathrm{N}$ varies with the cropping system; and ii) to determine the most appropriate model to describe net $\mathrm{N}$ mineralization amounts and rates.

\section{Materials and methods}

\section{Site description and cropping systems}

The soils used in this study were from the long-term rotation experiment on a Vertisol at ICRISAT Asia Center Patancheru, near Hyderabad, India $\left(17^{\circ} 36^{\prime} \mathrm{N}\right.$, $78^{\circ} 16^{\prime} \mathrm{E}, 545 \mathrm{~m}$ altitude). Major characteristics of the Kasireddipalli soil series, a typic pellustert, have been described in detail by El-Swaify et al. (1985). The experiment was started in the rainy season of 1983. Eight cropping systems with 2-year rotations were selected: i) two rows of $S$ intercropped with one row of PP every year (S/PP-S/PP); ii) two rows of COP intercropped with one row of PP followed by $S$ in the rainy season and SF in the postrainy season (COP/PP$\mathrm{S}+\mathrm{SF}$ ); iii) S/PP-in the first year followed by $\mathrm{S}$ in the next rainy season and then $C P$ in the postrainy season (S+CP); iv) S/PP-S+SF; v) S+CP-S+CP; vi) $\mathrm{S}+\mathrm{CP}-$
S+SF; vii) S+SF-S+SF; viii) fallow (F) in the rainy season followed by $S$ in the postrainy season $(F+S)$ $\mathrm{F}+\mathrm{S}$.

All the crops were grown rainfed, and no mineral $\mathrm{N}$ was applied to any plot for the duration of the study. All the crops received $20 \mathrm{~kg} \mathrm{Pha}^{-1}$ per season as single super phosphate prior to sowing by placement method. The plots were tilled with a bullock-drawn cultivator and harrow after harvest. All the crops were grown on raised broadbeds of $1.5 \mathrm{~m}$ width. The rainy season crops were dry seeded manually, 7-10 days before onset of the monsoon. After germination, all the crops were thinned to the desired population levels (Table 1). At harvest, above-ground plant material, except fallen leaves, was removed from all of the plots. After the harvest of the ninth year crops, soil samples were collected from $0-20 \mathrm{~cm}$ depth in early May 1992 . Four replicated soil samples from each plot were obtained and combined to form one sample per plot. From the eight treatments and three replications in the field, a total of 24 surface soil samples were collected and used in this study. Soils were characterised by measurements of $\mathrm{pH}$, total $\mathrm{C}$ and $\mathrm{N}$, and extractable mineral $\mathrm{N}$.

\section{Potentially mineralizable $N$}

Mineralizable $\mathrm{N}$ was determined in triplicate from each treatment using a leaching incubation procedure (Stanford and Smith, 1972). Nonseived soil (50 g) and acid-washed sand $(50 \mathrm{~g})$ were mixed and placed in a Buchnner funnel $(7.5 \mathrm{~cm}$ dia) on top of a fine layer of glass wool on a fibre glass filter paper. The soil surface was covered with a glass wool layer to avoid disturbance to the soil surface during extractions. The soils were leached with $150 \mathrm{~mL} 0.01 \mathrm{M} \mathrm{CaCl}_{2}$ with $25 \mathrm{~mL}$ increments followed with $50 \mathrm{~mL} \mathrm{~N}$-free nutrient solution containing $0.002 \mathrm{MCaSO}_{4} .2 \mathrm{H}_{2} \mathrm{O}, 0.002 \mathrm{M}$ $\mathrm{MgSO}_{4} .7 \mathrm{H}_{2} \mathrm{O}, 0.005 \mathrm{M} \mathrm{Ca}\left(\mathrm{HPO}_{4}\right)_{2} .2 \mathrm{H}_{2} \mathrm{O}$, and 0.0025 $M \mathrm{~K}_{2} \mathrm{SO}_{4}$ (Stanford and Smith, 1972) at 0, 1, 2, 3, 4, $6,8,10,13,16$, and 20 weeks. The soils were incubated at $30^{\circ} \mathrm{C}$ in the dark with the moisture content maintained at $70 \%$ water holding capacity.

\section{Chemical analysis}

Soil $\mathrm{pH}$ was measured by mixing $20 \mathrm{~g}$ soil with $40 \mathrm{~mL}$ distilled water and stirred frequently for $30 \mathrm{~min}$. Organic $\mathrm{C}$ content was estimated by dispersing $2 \mathrm{~g}$ sieved soil in $10 \mathrm{~mL}$ of $1 \mathrm{~N} \mathrm{~K}_{2} \mathrm{Cr}_{2} \mathrm{O}_{7}$ and $20 \mathrm{~mL}$ conc. $\mathrm{H}_{2} \mathrm{SO}_{4}$ containing $1.5 \%$ silver sulphate was added. After 30 $\min , 200 \mathrm{~mL}$ distilled water was added and using $\mathrm{O}$ - 
Table 1. Details of the cropping systems used in this study

\begin{tabular}{|c|c|c|c|c|c|c|c|c|}
\hline \multirow[b]{3}{*}{$\begin{array}{l}\text { Cropping } \\
\text { system }\end{array}$} & \multicolumn{4}{|c|}{ Year 1} & \multicolumn{4}{|c|}{ Year 2} \\
\hline & \multicolumn{2}{|c|}{$\begin{array}{l}\text { Rainy } \\
\text { season }\end{array}$} & \multicolumn{2}{|c|}{ Postrainy season } & \multicolumn{2}{|c|}{$\begin{array}{l}\text { Rainy } \\
\text { season }\end{array}$} & \multicolumn{2}{|c|}{ Postrainy season } \\
\hline & Crop & $\begin{array}{l}\text { Plant } \\
\text { pop } \times \\
\text { ha }^{-1}\end{array}$ & Crop & $\begin{array}{l}\text { Plant } \\
\text { pop } \times \\
\text { ha }^{-1}\end{array}$ & Crop & $\begin{array}{l}\text { Plant } \\
\text { pop } \times \\
\text { ha }^{-1}\end{array}$ & Crop & $\begin{array}{l}\text { Plant } \\
\text { pop } \times \\
\text { ha }^{-1}\end{array}$ \\
\hline \multirow[t]{2}{*}{ S/PP-S/PP } & $S$ & 120,000 & $b$ & - & $S$ & 120,000 & - & - \\
\hline & PP & 40,000 & - & - & $\mathrm{PP}$ & 40,000 & - & - \\
\hline COP/PP & $\mathrm{COP}$ & 180,000 & - & - & $S$ & 120,000 & SF & 60,000 \\
\hline $\mathrm{S}+\mathrm{SF}$ & PP & 40,000 & - & - & & & & \\
\hline \multirow[t]{2}{*}{$\mathrm{S} / \mathrm{PP}-\mathrm{S}+\mathrm{CP}$} & $S$ & 120,000 & - & - & $S$ & 120,000 & $\mathrm{CP}$ & 240,000 \\
\hline & $\mathrm{PP}$ & 40,000 & - & - & & & & \\
\hline \multirow[t]{2}{*}{$\mathrm{S}+\mathrm{PP}-\mathrm{S}+\mathrm{SF}$} & $S$ & 120,000 & - & - & $S$ & 120,000 & $\mathrm{SF}$ & 60.000 \\
\hline & $\mathrm{PP}$ & 40,000 & - & - & & & & \\
\hline $\mathrm{S}+\mathrm{CP}-\mathrm{S}+\mathrm{CP}$ & $S$ & 120,000 & $\mathrm{CP}$ & 240,000 & $S$ & 120,000 & $\mathrm{CP}$ & 240,000 \\
\hline $\mathrm{S}+\mathrm{CP}-\mathrm{S}+\mathrm{SF}$ & $\mathrm{S}$ & 120,000 & $\mathrm{CP}$ & 240,000 & $S$ & 120,000 & $\mathrm{SF}$ & 60,000 \\
\hline $\mathrm{S}+\mathrm{SF}-\mathrm{S}+\mathrm{SF}$ & $S$ & 120,000 & SF & 60,000 & $S$ & 120,000 & SF & 60,000 \\
\hline $\mathrm{F}+\mathrm{S}-\mathrm{F}+\mathrm{S}$ & - & - & $S$ & 60,000 & - & - & $S$ & 60,000 \\
\hline
\end{tabular}

${ }^{a} \mathrm{~S} / \mathrm{PP}-\mathrm{S} / \mathrm{PP}=$ two rows of $\mathrm{S}$ intercropped with one row of $\mathrm{P}$ every year; COP/PP-S+SF $=$ two rows of COP intercropped with one row of PP in the first year followed by $S$ in the next rainy season and $S F$ in the postrainy season; $\mathrm{S} / \mathrm{PP}-\mathrm{S}+\mathrm{CP}=\mathrm{S} / \mathrm{PP}$ in the first year followed by $\mathrm{S}$ in the next rainy season and then $\mathrm{CP}$ in the postrainy season; $\mathrm{S} / \mathrm{PP}-\mathrm{S}+\mathrm{SF}=\mathrm{S} / \mathrm{PP}$ in the first year followed by $\mathrm{S}$ in the next rainy season and then $\mathrm{SF}$ in the postrainy season; $\mathrm{S}+\mathrm{SF}-\mathrm{S}+\mathrm{SF}=\mathrm{S}$ in the rainy season followed by $\mathrm{SF}$ in the postrainy season each year; $S+C P-S+S F=S$ in the rainy season followed by $C P$ in the postrainy season and followed by $S$ in the next rainy season and SF in the postrainy season; $S+C P-S+C P=S$ in the rainy season followed by $\mathrm{CP}$ in the postrainy season each year; $\mathrm{F}+\mathrm{S}-\mathrm{F}+\mathrm{S}=$ fallow in the rainy season followed by $\mathrm{S}$ in the postrainy season each year.

${ }^{b}$ No crop was grown in postrainy season as pigeonpea sown in rainy season continued to grow upto December end or soil was kept fallow in rainy season as per the treatment.

Phenathroline indicator the samples were titrated with $0.5 \mathrm{~N} \mathrm{FeSO}_{4}$ solution (Nelson and Sommers 1982). Total $\mathrm{N}$ content in soil was estimated by adding $5 \mathrm{~mL}$ of $20 \% \mathrm{Na}_{2} \mathrm{~S}_{2} \mathrm{O}_{3}$ solution and then digesting with $15 \mathrm{~g}$ $\mathrm{Na}_{2} \mathrm{SO}_{4}, 1.5 \mathrm{~g} \mathrm{CuSO}_{4} .5 \mathrm{H}_{2} \mathrm{O}$ and $30 \mathrm{~mL}$ Con. $\mathrm{H}_{2} \mathrm{SO}_{4}$. The digest was diluted with water, distilled with $40 \%$ $\mathrm{NaOH}$ and titrated with $0.025 \mathrm{~N} \mathrm{H}_{2} \mathrm{SO}_{4}$ (Dalal et al., 1984). Mineral $\mathrm{N}\left(\mathrm{NH}_{4}+\mathrm{NO}_{3}-\mathrm{N}\right)$ content in soil was estimated by extracting soil with $2 N \mathrm{KCl}(1: 5 \mathrm{w} / \mathrm{v})$ after shaking for an hour. The soil extracts were filtered through Whatman No. 1 filter paper and aliquots of $\mathrm{KCl}$ extracts and $\mathrm{CaCl}_{2}$ leachates were analyzed for $\mathrm{NO}_{3}^{-}$and $\mathrm{NH}_{4}^{+}-\mathrm{N}$ by distilling the aliquot in a
microKjeldahl apparatus using $\mathrm{MgO}$ and Devarda's alloy (Jackson, 1973).

\section{Mathematical and statistical analyses}

The data were subjected to an analysis of variance and treatments were compared using the ' $F$ ' test of significance and least square difference (Panse and Sukhatme, 1957). A non-linear least squares fitting procedure was used for the exponential and hyperbolic models; a linear regression package was used for the linear model (SAS, 1987). Three models were used. 
The first was linear:

$$
N_{t}=\chi \times t
$$

where $\mathrm{N}_{t}$ is the net quantity of $\mathrm{N}$ mineralized (mg $\left.\mathrm{kg}^{-1}\right), \chi$ is the zero order rate constant $\left(\mathrm{mg} \mathrm{kg}^{-1}\right.$ $\mathrm{wk}^{-1}$ ) and $\mathrm{t}$ is time (wk). The second was an exponential model describing net accumulation of mineral $\mathrm{N}$ during first order decomposition of $\mathrm{N}$ from a potentially mineralizable $\mathrm{N}$ source:

$$
N_{t}=N_{o}[1-\exp (-k \times t)]
$$

where $\mathrm{N}_{t}$ is the cumulative net $\mathrm{N}$ mineralized (mg $\mathrm{kg}^{-1}$ ) over time $\mathrm{t}(\mathrm{wk}), \mathrm{k}$ is the first order rate constant (wk ${ }^{-1}$ ) and $\mathrm{N}_{o}$ is the potentially mineralizable $\mathrm{N}$ at $t=0$. The hyperbolic equation comprised the third model:

$$
N_{t}=N_{0} \times t /\left(T_{\mathrm{c}}+t\right)
$$

where $\mathrm{N}_{o}, \mathrm{~N}_{t}$, and $t$ are as defined above; $\mathrm{T}_{c}$ is the time (wk) required for mineralization of half the potentially mineralizable $\mathrm{N}\left(\mathrm{N}_{o}\right)$. The more complex models were compared to simpler models using the "F" statistic (Robinson, 1985) to determine if the reduction in the residual sum of squares (RSS) justified the increased model complexity. The " $F$ " statistic was the quotient of the difference between the RSS of the two models divided by the residual mean square (RMS) of the more complex model. The result was compared to an " $\mathrm{F}$ " value at $p<0.05$ with 1 and $\mathrm{n}-\mathrm{p}$ degrees of freedom, where $n=$ number of data points and $p=$ the number of estimated parameters in the model. The linear models were compared as paired treatments, with homogeneity of slope as the null hypothesis using an F-test of covariance.

\section{Results}

Mineral $N$, total $N$ and organic $C$ contents of the surface soil samples collected prior to the beginning of tenth season varied with cropping history (Table 2). Soil pH after 20 wk incubation was generally slightly lowered in all the soils, but the changes were not significant (results not shown).

\section{Mineral $N$ accumulation}

Mineral $\mathrm{N}$ leached from the soils under different cropping systems ranged from 1.9 to $13.6 \mathrm{mg} \mathrm{kg}^{-1}$ dry soil $\mathrm{wk}^{-1}$ at week one and similar results were observed

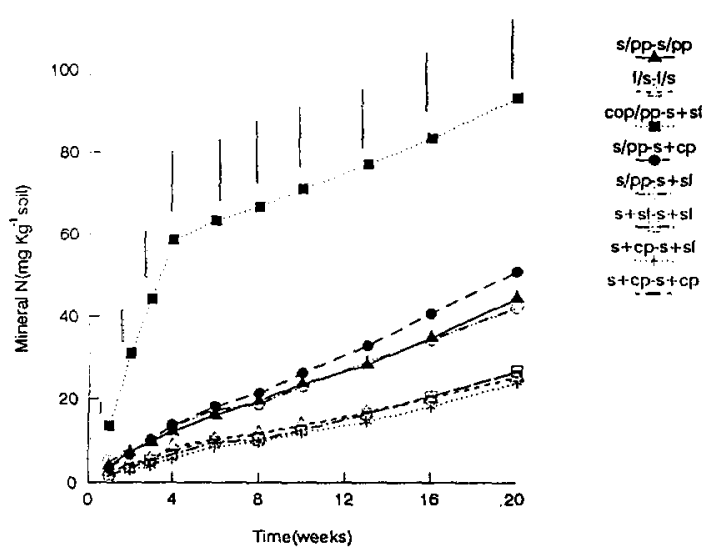

Fig. 1. Cumulative mineral $\mathrm{N}$ ( $\mathrm{mg} \mathrm{kg}^{-1}$ soil) during 20 weeks incubation of a Vertisol under different cropping systems. The bars represent SE to compare the treatments at a particular incubation period.

up to the fourth week; however, these values were not significantly different between treatments. From week six onwards mineral $\mathrm{N}$ extracted per week from different soils varied significantly $(p<0.05)$ and these differences persisted until week 20 (data not shown). Cumulative mineral $\mathrm{N}$ accumulation during incubation of 20 weeks varied significantly $(p<0.05)$ with the cropping history of the soil (Fig. 1). The rate of net $\mathrm{N}$ mineralization from all the soils was initially high and declined during later stages of incubation but remained greater than zero in all the soils throughout the incubation period.

\section{Mathematical analysis of mineral $N$ accumulation}

The first order exponential model yielded $\mathrm{N}_{o}$, values ranging from 40 to $100 \mathrm{mg} \mathrm{kg}^{-1}$ dry soil for six different cropping systems plots (Table 3 ). For the remaining two treatments (S+SF-S+SF and S+CP-S+SF), $\mathrm{N}_{o}$ values were not estimated as the exponential model was not found to be superior to the linear model. Estimated $\mathrm{N}_{0}$ values were highest for S/PP-S+CP followed by S/PP-S/PP, COP/PP-S+SF $>$ S/PP-S+SF, S+CP$\mathrm{S}+\mathrm{CP}>\mathrm{F}+\mathrm{S}-\mathrm{F}+\mathrm{S}$. The first order rate constant of $\mathrm{N}$ mineralization (k) varied from 0.021 to $0.223 \mathrm{wk}^{-1}$, and was highest in the COP/PP-S+SF cropping system (Table 3). $\mathrm{N}_{o}$ values estimated using the hyperbolic model varied from 45.1 to $109.4 \mathrm{mg} \mathrm{kg}^{-1}$ soil in different cropping systems. Generally, $\mathbf{N}_{o}$ values estimated using the hyperbolic model were higher than the values obtained from the exponential model, except in three cropping systems. However, $T_{c}$ values for all the 
Table 2. Properties of soil samples collected from long-term plots under different cropping systems

\begin{tabular}{|c|c|c|c|c|}
\hline \multirow[t]{2}{*}{ Treatment $^{a}$} & \multirow[t]{2}{*}{$\mathrm{pH}$} & Organic C & Total N & \multirow{2}{*}{$\begin{array}{c}\text { Mineral N } \\
\left(\mathrm{NH}_{4}+\mathrm{NO}_{3}-\mathrm{N}\right)^{b} \\
\left(\mathrm{mg} \mathrm{kg}^{-1} \text { soil }\right)\end{array}$} \\
\hline & & \multicolumn{2}{|c|}{ ( $\mathrm{g} \mathrm{kg}^{-1}$ dry soil) } & \\
\hline $\begin{array}{l}\text { S/PP-S/PP } \\
2: 1\end{array}$ & 8.12 & 4.7 & 0.632 & 11.2 \\
\hline $\begin{array}{l}\text { COP/PP-S+SF } \\
2: 1\end{array}$ & 8.00 & 4.6 & 0.625 & 9.7 \\
\hline $\begin{array}{l}\text { S/PP-S+CP } \\
2: 1\end{array}$ & 8.04 & 4.9 & 0.616 & 12.2 \\
\hline $\begin{array}{l}\text { S/PP-S+SF } \\
2: 1\end{array}$ & 8.02 & 4.5 & 0.597 & 4.01 \\
\hline $\mathrm{S}+\mathrm{CP}-\mathrm{S}+\mathrm{CP}$ & 7.97 & 4.1 & 0.529 & 8.00 \\
\hline $\mathrm{S}+\mathrm{CP}-\mathrm{S}+\mathrm{SF}$ & 7.90 & 3.8 & 0.534 & 7.1 \\
\hline $\mathrm{S}+\mathrm{SF}-\mathrm{S}+\mathrm{SF}$ & 8.06 & 4.2 & 0.547 & 7.06 \\
\hline $\mathrm{F}+\mathrm{S}-\mathrm{F}+\mathrm{S}$ & 8.17 & 3.8 & 0.489 & 4.8 \\
\hline $\mathrm{SE} \pm$ & 0.035 & 0.162 & 0.011 & 1.36 \\
\hline
\end{tabular}

a Numbers represent the ratio of number of rows of a crop in a particular intercropping system, details same as mentioned in the footnote of Table 1.

${ }^{b}$ Extracted with $2 \mathrm{M} \mathrm{KCl}$.

cropping systems were similar, ranging from 19.99 to 20.02 wk (data not shown). The "active $\mathrm{N}$ fraction", the quotient of $\mathrm{N}_{o}$ and $\mathrm{N}_{\text {tot }}\left(\mathrm{N}_{\text {tot }}=\right.$ total $\left.\mathrm{N}\right)$ expressed as a percentage, varied between 8 and $16 \%$ as estimated from the exponential model $\mathrm{N}_{o}$ values, and between 9 and $17 \%$ using the hyperbolic models (Table 3 ). Active $\mathrm{N}$ fraction values based on $\mathrm{N}_{o}$ values from exponential and hyperbolic models were similar for a particular soil.

\section{Comparison of models to describe mineral $N$ accumulation}

The RSS values obtained with the hyperbolic model were higher than with the linear and exponential models (data not shown). Consequently the hyperbolic model was not pursued further. The RSS values were lower in the exponential than in the linear model. The " $F$ " - ratios for the exponential model were significant- ly higher than those for the linear model in six out of eight soils, indicating that mineral $\mathrm{N}$ accumulation curves are described more closely by the exponential model than the linear model. For two soils from S+SF$\mathrm{S}+\mathrm{SF}$ and $\mathrm{S}+\mathrm{CP}-\mathrm{S}+\mathrm{SF}$, mineral $\mathrm{N}$ accumulation curves were described better by the linear than by the exponential model as evident from the nonsignificant ' $F$ ' values (1-1.3) for the exponential model over the linear model (Table 4). Cropping systems were ranked based on the time required to mineralize a fixed quantity (25 and $50 \mathrm{mg} \mathrm{N} \mathrm{kg}^{-1}$ soil) of $\mathrm{N}$ from the soil, as calculated from the linear and exponential models. Time required to mineralize $25 \mathrm{mg} \mathrm{N} \mathrm{kg}^{-1}$ soil varied from 1.5 to $19.6 \mathrm{wk}$ using the exponential model (Table 5). Although the two models gave different values for this, the rankings of the cropping systems remained almost the same irrespective of which model was used (Table 5). For both models, cropping systems which contained PP required less time to mineralize a 
Table 3. Nitrogen mineralization potentials $\left(\mathrm{N}_{o}\right)$, rate constants $(\mathbf{k})$ as estimated by exponential model and active $\mathrm{N}$ fraction of the soils under different cropping systems

\begin{tabular}{|c|c|c|c|c|c|c|}
\hline \multirow[b]{2}{*}{ Treatment } & \multirow{2}{*}{$\begin{array}{l}\mathrm{N}_{0} \\
\text { (mg kg-1 } \\
\text { soil) }\end{array}$} & \multirow[b]{2}{*}{$\mathrm{SE}$} & \multirow[b]{2}{*}{$\begin{array}{l}\mathrm{k} \\
\left(\mathrm{wk}^{-1}\right)\end{array}$} & \multirow[b]{2}{*}{$\mathrm{SE}$} & \multicolumn{2}{|c|}{ Active $\mathrm{N}$ fraction (\%) } \\
\hline & & & & & $\begin{array}{l}\text { Exponen- } \\
\text { tial }\end{array}$ & Hyperbolic \\
\hline S/PP-S/PP & $94.6^{a b}$ & 15.98 & 0.030 & 0.006 & 15 & 13 \\
\hline COP/PP-S+SF & $86.1^{a b}$ & 19.90 & 0.223 & 0.148 & 14 & 17 \\
\hline $\mathrm{S} / \mathrm{PP}-\mathrm{S}+\mathrm{CP}$ & $100.0^{a}$ & 10.04 & 0.021 & 0.005 & 16 & 16 \\
\hline S/PP-S+SF & $67.3^{b c}$ & 13.46 & 0.0461 & 0.013 & 11 & 13 \\
\hline $\mathrm{S}+\mathrm{CP} \cdot \mathrm{S}+\mathrm{CP}$ & $56.1^{b c}$ & 20.98 & 0.030 & 0.014 & 11 & 9 \\
\hline $\mathrm{S}+\mathrm{CP}-\mathrm{S}+\mathrm{SF}$ & $z$ & - & - & - & - & 9 \\
\hline $\mathrm{S}+\mathrm{SF}-\mathrm{S}+\mathrm{SF}$ & - & - & - & - & - & 9 \\
\hline $\mathrm{F}+\mathrm{S}-\mathrm{F}+\mathrm{S}$ & $40.5^{c}$ & 8.06 & 0.045 & 0.012 & 8 & 9 \\
\hline
\end{tabular}

Values with different letters varied significantly $(p \leq 0.05)$ from each other according to a ' $t$ ' test.

$z_{-}=$Not calculated, as the exponential model was not found superior to the linear model.

fixed quantity of $\mathrm{N}$ than did $\mathrm{CP}$-based systems or that contained no legume or were left fallow for one season (Table 5). Instantaneous rates of $\mathrm{N}$ mineralization for soils were calculated using linear and exponential models. Exponential model rates were initially higher than linear model rates, but reverse was true in the later stages of incubation. For the COP/PP-S+SF treatment the instantaneous rate of $\mathrm{N}$ mineralization was far higher than in other treatments up to the eighth week but decreased drastically at weeks 16 and 20 (Table 6). The zero order rate of $\mathrm{N}$ mineralization using the linear model for soil samples varied from 1.33 to 5.95 $\mathrm{mg} \mathrm{kg}{ }^{-1}$ soil $\mathrm{wk}^{-1}$, with a maximum rate of $\mathrm{N}$ mineralization from samples in the order COP/PP-S+SF $>$ S/PP-S+CP, S/PP-S/PP, S/PP-S+SF > S+CP-S+CP, $\mathrm{F}+\mathrm{S}-\mathrm{F}+\mathrm{S}, \mathrm{S}+\mathrm{SF}-\mathrm{S}+\mathrm{SF}>\mathrm{S}+\mathrm{CP}-\mathrm{S}+\mathrm{SF}$ (Table 6).

\section{Discussion}

Legumes can improve soil fertility or increase yield of the following crop, these benefits largely depend upon the total plant biomass produced, amount of $\mathrm{N}_{2}$ fixed, amount of $\mathrm{N}$ added to the soil through roots, nodules and the leaf fall (Wani et al., 1994c). The benefits in terms of increased $\mathrm{N}_{o}$ values in case of PP-based systems were observed when all the above-ground plant parts, except fallen leaves, were removed. Average above-ground total plant biomass over the previous nine years for PP varied from 3.0 to $4.1 \mathrm{t} \mathrm{ha}^{-1} \mathrm{y}^{-1}$ in different cropping systems; for $\mathrm{CP}$ it was around $1.7 \mathrm{t}$ $\mathrm{ha}^{-1} \mathrm{y}^{-1}$ and for COP it was $2 \mathrm{tha}^{-1} \mathrm{y}^{-1}$. Pigeonpea produces higher ( $20 \%$ of total plant biomass) root mass (Kumar Rao and Dart, 1977) and considerable amount of leaf fall than $\mathrm{CP}$ and other crops. Pigeonpea on an average added $700 \mathrm{~kg}$ root dry matter containing 7-10 $\mathrm{kg} \mathrm{N} \mathrm{ha}^{-1}$ (1-1.5\% total $\mathrm{N}$ ) and 2,500 to 3,000 kg dry leaf matter containing $37-45 \mathrm{~kg} \mathrm{~N}^{-1}(1.5 \% \mathrm{~N})$ to the soil. On the contrary, in CP-based systems only $170 \mathrm{~kg} \mathrm{ha}^{-1}$ root dry matter containing $1.7 \mathrm{~kg} \mathrm{~N} \mathrm{ha}^{-1}$ (with $1 \% \mathrm{~N}$ ) and $500 \mathrm{~kg}$ leaf dry matter containing 8 $\mathrm{kg} \mathrm{N} \mathrm{ha}^{-1}(1.6 \% \mathrm{~N})$ was added to soil each year. In PP-based systems, $42-55 \mathrm{~kg}$ of plant $\mathrm{N} \mathrm{ha}^{-1} \mathrm{y}^{-1}$ was added to soil through root matter and leaf fall, whereas $\mathrm{CP}$ added around $10 \mathrm{~kg} \mathrm{~N} \mathrm{ha}^{-1} \mathrm{y}^{-1}$ to soil. Further, PP derived upto $88 \%$ of its $\mathrm{N}$ requirement through BNF whereas at Patancheru (Peninsular India) CP fixed 3-4 times less nitrogen than in the northern India (Nambiar 
Table 4. Evaluation of models to describe $\mathrm{N}$ mineralization potential $\left(\mathrm{N}_{o}\right)$ and the rate constant $(k)$ with time ( $t$ ) for the soils under different cropping systems

\begin{tabular}{|c|c|c|c|c|c|}
\hline Treatment & Model & RSS & RMS & F ratio & $\%$ TSS \\
\hline \multirow[t]{2}{*}{ S/PP-S/PP } & Linear & 154.2 & 5.3 & & 96.6 \\
\hline & Exponential & 85.2 & 3.0 & $22.7^{* *}$ & 99.5 \\
\hline \multirow[t]{2}{*}{ COP/PP-S+SF } & Linear & 81432 & 2808 & & 3.4 \\
\hline & Exponential & 68807 & 2457.4 & $5.1^{*}$ & 64.4 \\
\hline \multirow[t]{2}{*}{ S/PP-S+CP } & Linear & 119.9 & 4.1 & & 98.1 \\
\hline & Exponential & 73.3 & 2.6 & $17.8^{* *}$ & 99.7 \\
\hline \multirow[t]{2}{*}{ S/PP-S+SF } & Linear & 454.0 & 15.7 & & 89.2 \\
\hline & Exponential & 304.7 & 10.9 & $13.7^{* *}$ & 98.1 \\
\hline \multirow[t]{2}{*}{$\mathrm{S}+\mathrm{CP}-\mathrm{S}+\mathrm{CP}$} & Linear & 173.9 & 6.0 & & 89.8 \\
\hline & Exponential & 149.7 & 5.3 & $4.5^{*}$ & 97.5 \\
\hline \multirow[t]{2}{*}{$S+C P-S+S F$} & Linear & 65.3 & 2.2 & & 95.4 \\
\hline & Exponential & 62.3 & 2.2 & $1.3^{\mathrm{NS}}$ & 98.6 \\
\hline \multirow[t]{2}{*}{ S+SF-S+SF } & Linear & 65.6 & 2.3 & & 96.2 \\
\hline & Exponential & 63.3 & 2.3 & $1.0^{\mathrm{NS}}$ & 98.9 \\
\hline \multirow[t]{2}{*}{$F+S-F+S$} & Linear & 149.4 & 5.1 & & 89.9 \\
\hline & Exponential & 109.4 & 3.6 & $13.7^{* *}$ & 98.2 \\
\hline
\end{tabular}

${ }^{*}=p<0.05,{ }^{* *}=p<0.01$, NS - not significant, RSS - Residual sum of squares, RMS - residual mean square, \% TSS - \% total sum of squares.

et al., 1988). In case of PP leaf fall starts in the rainy season and lower layers of leaf matter start decomposing as moisture is available. During receding soil moisture and dry period considerable straw foraging activity of the termites in SAT fields was observed (Reddy et al., 1994). During eight rain-free weeks after incorporating labelled groundnut straw, $12 \%$ of ${ }^{14} \mathrm{C}$ added to Vertisol was lost and during next four wet weeks (rainy season), further $38 \%$ of added ${ }^{14} \mathrm{C}$ was lost. At the end of second year, in all $72 \%$ of added ${ }^{14} \mathrm{C}$ was lost from the soil (Stephan Singer, pers. commun.). In addition to the more quantity of organic matter added to soil by PP, the quality of PP dry matter also may have effect on increasing $\mathrm{N}_{o}$ estimates. Thus, it leads to a cumulative effect of $\mathrm{N}$ mineralization year after year in PP-based systems due to more addition and probably better quality of plant dry matter resulting in two times increased $\mathrm{N}_{o}$ values in PP-based systems than the $\mathrm{N}_{o}$ values in $\mathrm{F}+\mathrm{S}-\mathrm{F}+\mathrm{S}$ and $\mathrm{CP}$-based systems. Such increased $\mathrm{N}_{o}$ values were observed with green manuring over a continued wheat system without fertilizer addition for Black Chernozemic samples (Campbell et al., 1991). Similarly, for Gray Luvisols, legume-based rotations were associated with increased total soil $\mathrm{N}$ and a greater proportional increase in active $\mathrm{N}$ than in total soil $\mathrm{N}$ (Wani et al., 1994a). Although $\mathrm{N}_{0}$ values differed with the cropping systems, the leaching method could underestimate the mineralizable $\mathrm{N}$ content in soils as soluble organic $\mathrm{N}$ is also leached out with the mineral $\mathrm{N}$. The values for the $\mathrm{N}$ mineralization rate constant $(\mathrm{k})$ varied between 0.021 and $0.223 \mathrm{wk}^{-1}$, but, such differences were not statistically significant. The $\mathrm{k}$ values were higher (although statistically not significant) in soil from COP/PP plots, as compared to other treatments. This could be due to the succulent nature of COP roots and higher amounts of root nodules left in the top $20 \mathrm{~cm}$ layer. Also, COP was harvested two months earlier than PP, and the COP root 
Table 5. Time (wk) required to mineralize a fixed amount of $\mathrm{N}$ in soil samples of different cropping systems incubated at $30^{\circ} \mathrm{C}$ using exponential and linear models

\begin{tabular}{|c|c|c|c|c|c|c|}
\hline \multirow[b]{3}{*}{ Treatment } & & & \multicolumn{4}{|c|}{$\begin{array}{l}\text { Time (wk) to mineralize } \\
\left(\mathrm{mg} \mathrm{N} \mathrm{kg}^{-1}\right)\end{array}$} \\
\hline & \multicolumn{2}{|c|}{ Rank } & \multicolumn{2}{|c|}{25} & \multicolumn{2}{|c|}{50} \\
\hline & Linear & $\begin{array}{l}\text { Expo- } \\
\text { nential }\end{array}$ & Linear & $\begin{array}{l}\text { Expo- } \\
\text { nential }\end{array}$ & Linear & $\begin{array}{l}\text { Expo } \\
\text { nential }\end{array}$ \\
\hline S/PP-S/PP & 3 & 3 & 10.95 & 10.26 & 21.91 & 25.15 \\
\hline $\mathrm{COP} / \mathrm{PP}-\mathrm{S}+\mathrm{SF}$ & 1 & 1 & 4.20 & 1.54 & 8.41 & 3.9 \\
\hline $\mathrm{S} / \mathrm{PP}-\mathrm{S}+\mathrm{CP}$ & 2 & 4 & 9.60 & 13.76 & 19.19 & 33.2 \\
\hline S/PP-S+SF & 4 & 2 & 11.13 & 10.06 & 22.26 & 29.44 \\
\hline $\mathrm{S}+\mathrm{CP}-\mathrm{S}+\mathrm{CP}$ & 5 & 5 & 18.40 & 19.61 & 36.79 & 73.81 \\
\hline $\mathrm{S}+\mathrm{CP}-\mathrm{S}+\mathrm{SF}$ & 8 & $-a$ & 20.99 & - & 41.98 & - \\
\hline S+SF-S+SF & 7 & - & 18.85 & - & 37.71 & - \\
\hline $\mathrm{F}+\mathrm{S}-\mathrm{F}+\mathrm{S}$ & 6 & 6 & 18.82 & 21.4 & 37.65 & - \\
\hline
\end{tabular}

${ }^{a}$ Not calculated as the exponential model was not superior to the linear model.

Table 6. Instantaneous rate of $\mathrm{N}$ mineralization ( $\mathrm{mg} \mathrm{N} \mathrm{kg}^{-1}$ week ${ }^{-1}$ ) in soils from different cropping systems using linear and exponential models

\begin{tabular}{llllllll}
\hline & & \multicolumn{5}{c}{ Exponential model } \\
\cline { 3 - 7 } Treatment & $\begin{array}{l}\text { Linear } \\
\text { model }\end{array}$ & 0 & 2 & 8 & 16 & 20 \\
\hline S/PP-S/PP & $2.28^{b}$ & 2.83 & 2.66 & 2.23 & 1.75 & 1.55 \\
COP/PP-S+SF & $5.95^{a}$ & 19.20 & 12.29 & 3.22 & 0.54 & 0.22 \\
S/PP-S+CP & $2,60^{b}$ & 2.09 & 2.00 & 1.77 & 1.50 & 1.38 \\
S/PP-S+SF & $2.25^{b}$ & 3.10 & 2.83 & 2.15 & 1.48 & 1.23 \\
S+CP-S+CP & $1.36^{c}$ & 1.69 & 1.59 & 1.33 & 1.04 & 0.92 \\
S+CP-S+SF & $1.19^{d}$ & $-z$ & - & - & - & - \\
S+SF-S+SF & $1.33^{c}$ & - & - & - & - & - \\
F+S-F+S & $1.33^{c}$ & 1.82 & 1.66 & 1.27 & 0.89 & 0.74 \\
\hline
\end{tabular}

Values with different letters varied significantly from each other. ${ }^{z}$ Not calculated as the exponential model was not superior to the linear model. 
material in the soil could have decomposed more readily than that of PP. In other treatments which included S, net mineralisation in the presence of $S$ plant roots with higher $\mathrm{C}: \mathrm{N}$ ratio might have delayed $\mathrm{N}$ release through increased immobilisation. The instantaneous rate of $\mathrm{N}$ mineralization based on quantity of mineral $\mathrm{N}$ leached in COP/PP treatment was far lower than in other soils during later stages of incubation (Table 6). Soil organic $\mathrm{C}$ declined more rapidly in COP and soybean rotations than in maize (Lal, 1976). The relationship between the nature and quality of plant root material and rate of $\mathrm{C}$ and $\mathrm{N}$ mineralization, needs to be further investigated. For the semi-arid soils of Morocco, $\mathrm{k}$ values for 14 different soils ranged from 0.06 to $0.274 \mathrm{wk}^{-1}$ as calculated by the exponential model and from 0.024 to $0.212 \mathrm{wk}^{-1}$ according to the hyperbolic model (Soudi et al., 1990). For these soils $\mathrm{k}$ values ranged from 0.04 to $1.3 \mathrm{wk}^{-1}$, decreasing with the increasing soil depth. Wani et al. (1994a) observed a slightly higher rate constant for Gray Luvisols which had received fababean material as green manuring than the one which was continuously under continuous barley. Janzen (1987) found no effect of rotation treatments on $k$ values. On the contrary, $k$ has been reported to be a function of climate, soil type, and the length of incubation period used to determine this parameter (Cabrera and Kissel, 1988; Juma et al., 1984; Paustian and Bonde, 1987). Mineral $\mathrm{N}$ accumulation curves were described more closely by the exponential model than the linear model for six out of the eight soils used in this investigation and this is in conformity with the earlier findings (Gharous et al., 1990; Juma et al., 1984; Wani et al., 1994a). Based on $N_{o}$ and k parameters, several criteria such as the amount of $\mathrm{N}$ mineralized during selected periods of time under controlled conditions (Stanford et al., 1973), the time required to mineralize a fixed amount of N (Gharous et al., 1990; Wani et al., 1994a) and the instantaneous rate of $\mathrm{N}$ mineralization at $\mathrm{t}=0$ (Campbell et al., 1991; Wani et al., 1994a) have been used to compare $\mathrm{N}$ availability for plant growth among soils. As reported by Wani et al. (1994a) we observed no differences among these criteria for distinguishing soils under diverse cropping systems. The "active fraction" calculated from the ratio of $\mathrm{N}_{o} / \mathrm{N}_{\text {tot }}$ (McGill et al., 1988) constituted 8 to $16 \%$ of soil $\mathrm{N}$ in the present study and was affected by cropping history of the soil. The value was lowest in the $\mathrm{F}+\mathrm{S}-\mathrm{F}+\mathrm{S}$ treatment, and higher in PP-component systems. The "active fraction" for Gray Luvisols under diverse cropping systems varied between 12-27\%, and increased along with total soil $\mathrm{N}$ due to green manuring, straw application, manure and
P application (Wani et al., 1994a). Consequently, there was a positive relationship between $\mathrm{N}_{o} / \mathrm{N}_{\text {tot }}$ and total soil $\mathbf{N}$ for the eight soil samples investigated in this study. Simple linear regression on total soil $\mathrm{N}$ accounted for $76 \%$ of the variation in $\mathrm{N}_{o} / \mathrm{N}_{\text {tot }}$ (data not shown). This relationship must be interpreted with caution as it is based on only eight data points. Our findings are consistent with the findings of Wani et al. (1994a) and also with the hypothesis of McGill et al. (1988) which stated that, until the active fraction reached a steady state, during transitions of soil to more or less organic matter, a direct relation would exist between the proportion of soil $\mathrm{N}$ which is active (using $\mathrm{N}_{o}$ as surrogate) and total soil organic $\mathrm{N}$. This study showed that within nine years, PP-based cropping systems increased mineralizable $\mathrm{N}$ in the soil. Average $\mathrm{N}_{o}$ values for PP-based cropping systems were two-fold higher than in the $\mathrm{F}+\mathrm{S}$ $\mathrm{F}+\mathrm{S}$ or $\mathrm{S}+\mathrm{CP}-\mathrm{S}+\mathrm{CP}$ systems. These increases in mineralizable $\mathrm{N}$ contents were observed even when all the above-ground plant material, except fallen leaves, was removed from the plots. Increased $\mathrm{N}_{o}$ values in PPbased systems resulted in increasing yield of following sorghum crop ( $3.2 \mathrm{tha}^{-1}$ for COP/PP-S+SF and $2.3 \mathrm{t}$ $\mathrm{ha}^{-1}$ for S/PP-S+CP as compared to $1.4 \mathrm{t} \mathrm{ha}^{-1}$ from $\mathrm{S}+\mathrm{SF}-\mathrm{S}+\mathrm{F}$ and $1.9 \mathrm{t} \mathrm{ha}^{-1}$ from $\mathrm{S}+\mathrm{CP}-\mathrm{S}+\mathrm{SF}$ systems). Under tropical conditions also, even with removal of the above ground plant material, mineralizable nitrogen contents in Vertisols could be increased by intercropping a cereal with PP. However, such increased $\mathrm{N}_{o}$ values at Patancheru were not associated with another legume $(\mathrm{CP})$, which is grown during the postrainy season on residual moisture. At Patancheru temperatures are higher than in the chickpea-growing areas of northern India, and $\mathrm{N}_{2}$ fixation for $\mathrm{CP}$ has been reported to be 3-4 times as high as in peninsular India (Nambiar et al., 1988). In conclusion, for Vertisols in the tropics PP-based cropping systems, which derive considerable nitrogen through BNF, can increase soil $\mathrm{N}$ availability and sustain productivity of cropping systems.

\section{References}

Birch H F and Dougall H W 1967 Effect of a legume on soil nitrogen mineralization and percentage nitrogen in grasses. Plant and Soil 27, 292-296.

Cabrera M L and Kissel DE 1988 Length of incubation time affects the parameter values of the double exponential model of nitrogen mineralization. Soil Sci. Soc. Am. J. 52, 1186-1187.

Campbell C A and Souster W 1982 Loss of organic matter and potentially mineralizable nitrogen from Saskatchewan soils due to cropping. Can. J. Soil Sci. 62, 651-656. 
Campbell C A, LaFond G P, Leyshon A J, Zentner R P and Janzen H H 1991 Effect of cropping practices on the initial potential rate of $\mathrm{N}$ mineralization in a thin black Chernozem. Can. J. Soil Sci. $71,43-54$

Cook R J 1988 Biological control and holistic plant-health care in agriculture. Am. J. Alter. Agric. 3, 51-62.

Dalal R C, Sahrawat K L and Myers R J K 1984 Inclusion of nitrate nitrite in the Kjeldahl nitrogen determination of soils and plant materials using sodium thiosulphate. Commun. Soil Sci. Plant Anal. 15, 1453-1461.

El-Swaify S A, Pathak P, Rego T J and Singh S 1985 Soil management for optimized productivity under rainfed conditions in the semi-arid tropics. Adv. Soil Sci. 1, 1-64.

Fyson A and Oaks A 1990 Growth promotion of maize by legume soils. Plant and Soil 122, 259-266.

Gharous M E, Westerman R L and Soltanpaur P N 1990 Nitrogen mineralization potential of arid and semi-arid soils of Morocco. Soil Sci. Soc. Am. J. 54, 438-443.

Jackson M L 1973 Nitrogen determinations for soils and plant tissue. In Soil Chemical Analysis. pp 183-205. Prentice Hall of India Pvt. Ltd., New Delhi.

Janzen H H 1987 Soil organic matter characteristics after long-term cropping to various spring wheat rotations. Can. J. Soil Sci. 67, 845-856.

Juma N G, Paul E A and Mary B 1984 Kinetic analysis of net nitrogen mineralization in soil. Soil Sci. Soc. Am. J. 48, 753-757.

Kumar Rao J V D K, Dart P J and Sastry P V S S 1983 Residual effect of pigeonpea (Cajanus cajan) on yield and nitrogen response of maize. Exp. Agric. 19, 131-141.

Lal A 1976 No-tillage effect on soil properties under different crops in western Nigeria. Soil Sci. Soc. Am. J. 40, 762-768.

McGill W B 1983 Kinetic effects on quality of soil organic matter. In Proc. Alberta Soil Sci. Workshop, Edmonton. pp 1-9. CSSS, Edmonton, Alberta.

McGill W B, Cannon K R, Robertson J A and Cook F D 1986 Dynamics of soil microbial biomass and water-soluble organic $\mathrm{C}$ in Breton $\mathrm{L}$ after 50 years of cropping to two rotations. Can. J. Soil Sci. 66, 1-19.

McGill W B, Dormaar J F and Reinl-Dwyer E 1988 New perspectives on soil organic matter quality, quantity and dynamics on the Canadian Prairies. In Land Degradation and Conservation Tillage. pp 30-48. Proc 34th Annual CSSS/AIC meeting, Calgary, Alberta.

Nambiar P T C, Rupela O P and Kumar Rao J V D K 1988 Nodulation and nitrogen fixation in groundnut (Arachis hypogaea $\mathrm{L}$ ), chickpea (Cicer arietinum $\mathrm{L}$ ) and pigeonpea (Cajanus cajan $\mathrm{L}$ millsp). In Biological Nitrogen Fixation: Recent Developments. Ed. N S Subba Rao. pp 21-52. Oxford and WE Publishing Co Pvt Ltd, New Delhi.

Nelson D W and Sommers L E 1982 Total carbon, organic carbon, and organic matter. In Methods of Soil Analysis. Part II. Eds. A L Page, R H Miller and D R Keeney. pp 539-579. Am. Soc. Agron., Madison, WI.

Panse V G and Sukhatme P V 1957 Statistical Methods for Agricultural Workers. Indian Council for Agricultural Research, New Delhi.
Paustian K and Bonde T A 1987 Interpreting incubation data on nitrogen mineralization from soil organic matter. In Soil Organic Matter Dynamics and Soil Productivity. Ed. J H Cocley. Proc from an INTECOL Workshop. INTECOL Bull 15, 101-112. Int Assoc for Ecol Athens, Georgia.

Poyser E A, Hedlin R A and Ridley A O 1957 The effect of farm and green manures on the fertility of Blackearth-meadow clay soils. Can. J. Soil Sci. 37, 48-56.

Reddy M V, Reddy R V, Yule D F, Cogle A L and George P J 1994 Decomposition of straw in relation to tillage, moisture, and arthropod abundance in a semi-arid tropical Alfisol. Biol. Fertil. Soils $17,45-50$.

Rego T J and Burford J R 1992 Sustaining crop productivity on rainfed Vertisols through grain legumes. In Agronomy Abstracts, 1992. Annual Meetings American Society of Agronomy. p 289 Crop Sci. Soc. Am., Soil Sci. Soc. Am., Clay Minerals Soc. Minneapolis, Minnesota.

Robinson J A 1985 Determining microbial kinetic parameters using non-linear regression analysis: advantages and limitations in microbial ecology. Adv. Microbiol. Ecol. 3, 61-114.

SAS Institute 1987 SAS/Stat Guide for personal computers. SAS Inst., Cary, North Carolina.

Soudi B, Sabi A and Chiang C N 1990 Nitrogen mineralization in semi-arid soils of Morocco: rate constant variation with depth. Soil Sci. Soc. Am. J. 54, 756-761.

Stanford G and Smith S J 1972 Nitrogen mineralization potentials of soils. Soil Sci. Soc. Am. Proc. 36, 465-472.

Stanford G, Legg J O and Smith S J 1973 Soil nitrogen availability evaluations based on nitrogen mineralization potentials of soils and uptake of labeled and unlabeled nitrogen by plants. Plant and Soil 39, 113-124

Wani S P, McGill W B and Robertson J A 1991 Soil N dynamics and $\mathrm{N}$ yield of barley grown on Breton loam using $\mathrm{N}$ from biological fixation or fertilizer. Biol. Fertil, Soils 12, 10-18.

Wani S P, McGill W B, Hauugen-Kozyra K L and Juma N'G 1994a Increased proportion of active soil $\mathrm{N}$ in Breton loam under cropping systems with forages and green manures. Can. J. Soil Sci 74, 67-74.

Wani S P, McGill W B, Haugen-Kozyra K L, Robertson J A and Thurston J J 1994b Improved soil quality and barley yields with fababeans, manure, forages and crop rotation on a gray luvisol. Can. J. Soil Sci. 74, 75-84.

Wani S P, Rupela O P and Lee K K 1994c BNF technology for sustainable agriculture. In Transactions of the $15^{\text {th }}$ World Congress of Soil Science, 10-16 July 1994. pp 245-262. The International Society of Soil Science and The Mexican Society of Soil Science, Acapulco, Mexico.

Willey R W, Singh R P and Reddy M S 1989 Cropping systems for Vertisols in different rainfall regimes in the semi-arid tropics. In Management of Vertisols for improved Agricultural Production. Eds. J R Burford and K L Sahrawat. pp 119-132. Proceedings of an IBSRAM inaugural workshop held at ICRISAT Center, India, 18-22 February 1985, International Crops Research Institute for the Semi-Arid Tropics, Patancheru, India.

Section editor: $H$ Lambers 